\title{
Anti-fatigue activity of a mixture of seahorse (Hippocampus abdominalis) hydrolysate and red ginseng
}

\author{
Nalae Kang ${ }^{1}$, Seo-Young Kim', Sum Rho' ${ }^{2}$ Ju-Young Ko ${ }^{1 *+}$ and You-Jin Jeon ${ }^{1 *+}$
}

\begin{abstract}
Seahorse, a syngnathidae fish, is one of the important organisms used in Chinese traditional medicine. Hippocampus abdominalis, a seahorse species successfully cultured in Korea, was validated for use in food by the Ministry of Food and Drug Safety in February 2016; however. the validation was restricted to 50\% of the entire composition. Therefore, to use $\mathrm{H}$. abdominalis as a food ingredient, $\mathrm{H}$. abdominalis has to be prepared as a mixture by adding other materials. In this study, the effect of $\mathrm{H}$. abdominalis on muscles was investigated to scientifically verify its potential bioactivity. In addition, the anti-fatigue activity of a mixture comprising $\mathrm{H}$. abdominalis and red ginseng (RG) was evaluated to commercially utilize H. abdominalis in food industry. H. abdominalis was hydrolyzed using Alcalase, a protease, and the effect of $H$. abdominalis hydrolysate $(\mathrm{HH})$ on the muscles was assessed in $\mathrm{C} 2 \mathrm{C} 12$ myoblasts by measuring cell proliferation and glycogen content. In addition, the mixtures comprising $\mathrm{HH}$ and $\mathrm{RG}$ were prepared at different percentages of $\mathrm{RG}$ to $\mathrm{HH}(20,30,40,50,60,70$, and $80 \% \mathrm{RG})$, and the anti-fatigue activity of these mixtures against oxidative stress was assessed in $\mathrm{C} 2 \mathrm{C} 12$ myoblasts. In $\mathrm{C} 2 \mathrm{C} 12$ myoblasts, $\mathrm{H}_{2} \mathrm{O}_{2}$-induced oxidative stress caused a decrease in viability and physical fatigue-related biomarkers such as glycogen and ATP contents. However, treatment with $\mathrm{RG}$ and $\mathrm{HH}$ mixtures increased cell viability and the content of fatigue-related biomarkers. In particular, the $80 \%$ RG mixture showed an optimum effect on cell viability and ATP synthesis activity. In this study, all results indicated that $\mathrm{HH}$ had anti-fatigue activity at concentrations approved for use in food by the law in Korea. Especially, an 80\% RG to $\mathrm{HH}$ mixture can be used in food for ameliorating fatigue.
\end{abstract}

Keywords: Hippocampus abdominalis, Anti-fatigue activity, C2C12 myoblast, Mixture of Hippocampus abdominalis hydrolysate and red ginseng

\section{Background}

Seahorse is a well-known ingredient in traditional Chinese medicine and is used as an invigorant for the treatment of erectile dysfunction, impotence, wheezing, and nocturnal enuresis. Modern scientific research has proven the pharmaceutical effects of seahorse. Hippocampus kuda has various bioactivities such as anti-tumor, anti-aging, and anti-fatigue as well as $\mathrm{Ca}^{2+}$ channel blocking properties (Kumaravel et al. 2010). A peptide derived from H. kuda has been shown to be effective in chondrocytes and inflammatory arthritis (Kumaravel et al. 2012). In addition,

\footnotetext{
* Correspondence: herolegend@hanmail.net; youjin2014@gmail.com ${ }^{\dagger}$ Equal contributors

'Department of Marine Life Sciences, Jeju National University, Jeju 63243, Korea

Full list of author information is available at the end of the article
}

seahorses have a putative free radical scavenging effect in controlling aging process (Kumaravel et al. 2012). However, the natural source of seahorse has dramatically reduced owing to overfishing, unsustainable trade, and habitat destruction (Qian et al. 2012). Therefore, seahorses became the first commercially valuable marine genus to be protected and included in Appendix II of the Convention on International Trade in Endangered Species (CITES) in 2004 (Segade et al. 2015).

Hippocampus abdominalis is one of the largest seahorse species growing up to $35 \mathrm{~cm}$ in length (Perera et al. 2016). It was validated for use as a food ingredient by the Ministry of Food and Drug Safety in February 2016. However, the validation was restricted to $50 \%$ of the entire composition. For use in food, we should try to prepare a mixture of $H$. abdominalis by 
adding other materials. In addition, biological activities of $H$. abdominalis have rarely been reported so far.

Fatigue is a common distressing condition accompanied by a feeling of extreme physical or mental tiredness that often results in diverse disorders such as anemia, thyroid dysfunction, premature aging, and depression. It could also have adverse effects on work efficiency, physical activities, life quality, and social relationships (Huang et al. 2011). Fatigue is caused by sleep deprivation, inadequate rest, low mood, stress, nutritional imbalance, insufficient exercise, as well as side effects of medications. Chronic fatigue is a persistent unexplainable fatigue lasting for more than 6 months, and it is considered a complex symptom of various neurological, psychiatric, and systemic diseases (Huang et al. 2014). Recently, many researchers have presented the results on the anti-fatigue activity of natural products (Yu et al. 2008; Zhang et al. 2006). Especially, red ginseng has been mainly focused on its anti-fatigue activity with the ability mitigating exercise-related muscle damage, maintaining homeostasis of the body and enhancing vital energy (Kim et al. 2013; Kim et al. 2016). On the other hand, anti-fatigue activity of seahorse has not been scientifically proven although seahorse is a well-known traditional Chinese medicine.

Oxidative stress is caused by an imbalance between reactive oxygen species (ROS) and antioxidant molecules. Excess accumulation of ROS causes oxidative damage by reacting with biomolecules including DNA, membrane lipids, cellular proteins, and diverse pathological states (Kang et al. 2013). Oxidative stress and ROS are the most important causes of exercise-induced disturbances (Fan et al. 2016). In particular, an oxidative imbalance in the skeletal muscle results in increased muscle fatigability. Thus, antioxidants can be used to alleviate fatigue by counteracting the oxidative stress (Nam et al. 2016).

In this study, the effect of $H$. abdominalis on muscles was investigated to scientifically verify its potential bioactivity. Also, the anti-fatigue activity of a mixture comprising $H$. abdominalis and red ginseng was investigated to evaluate the synergy effect and to utilize $H$. abdominalis in the food market. The anti-fatigue activity of H. abdominalis and a mixture was evaluated by measuring the levels of physical fatigue-related biomarkers such as serum glycogen and ATP contents.

\section{Methods}

\section{Materials}

H. abdominalis was kindly donated by Corea Center of Ornamental Reef \& Aquariums CCORA (Jeju, Korea) and lyophilized at $-70{ }^{\circ} \mathrm{C}$ using a freeze dryer. The lyophilized $H$. abdominalis powder was stored at $-80{ }^{\circ} \mathrm{C}$ until use. Red ginseng extract containing 30\% saponin was purchased from ILHWA Co., LTD. (Gyeonggi, Korea) and lyophilized at $-70{ }^{\circ} \mathrm{C}$ using a freeze dryer. The lyophilized red ginseng powder was stored at $-80{ }^{\circ} \mathrm{C}$ until use. Alcalase, a commercial food-grade protease, was purchased from Novozyme Co. (Novozyme Nordisk, Bagsvaerd, Denmark). The other chemicals and reagents used were of analytical grade.

\section{Preparation of $\mathrm{H}$. abdominalis hydrolysate $(\mathrm{HH})$}

The enzymatic hydrolysis of $H$. abdominalis was performed using Alcalase under optimal conditions $\left(50{ }^{\circ} \mathrm{C}\right.$ and $\mathrm{pH}$ 8). The dried $H$. abdominalis powder was homogenized in distilled water and hydrolyzed using the enzyme at an enzyme/substrate (E/S) ratio of 1:100 for enzymatic reactions. The optimal $\mathrm{pH}$ of the homogenates was adjusted before enzymatic hydrolysis. The mixture was incubated for $24 \mathrm{~h}$ at the optimal temperature for each homogenate, with stirring, and then boiled for $10 \mathrm{~min}$ at $100{ }^{\circ} \mathrm{C}$ to inactivate the enzyme. After filtration, all hydrolysates were stored at $-70{ }^{\circ} \mathrm{C}$ for further experiments.

\section{Preparation of the $\mathrm{H}$. abdominalis mixture}

The $H$. abdominalis mixtures were prepared by adding different concentrations of red ginseng (RG). The lyophilized $H$. abdominalis powder and RG powder were mixed as indicated in Table 1 , and these seven mixtures were labeled as \% of RG.

\section{Cell culture}

The C2C12 myoblasts obtained from American Type Culture Collection (ATCC, Manassas, VA, USA) were cultured in Dulbecco's Modified Eagle Medium (DMEM) supplemented with $10 \%$ heat-inactivated fetal bovine serum (FBS), streptomycin $(100 \mathrm{mg} / \mathrm{mL})$, and penicillin $(100 \mathrm{u} / \mathrm{mL})$ at $37{ }^{\circ} \mathrm{C}$ in a $5 \% \mathrm{CO}_{2}$ humidified incubator. To induce differentiation, $80 \%$ confluent cultures were switched to DMEM containing $2 \%$ horse serum (HS) for 6 days with medium changes every other day.

\section{Cell viability}

The cytotoxicity of the samples on $\mathrm{C} 2 \mathrm{C} 12$ myoblasts was determined by colorimetric MTT assays. The cells

Table 1 Percentage of $\mathrm{HH}$ and $\mathrm{RG}$ to prepare the $\mathrm{H}$. abdominalis mixtures

\begin{tabular}{lll}
\hline $\mathrm{HH}(\%)$ & $\mathrm{RG}(\%)$ & The mixture (\%) \\
\hline 80 & 20 & 100 \\
70 & 30 & 100 \\
60 & 40 & 100 \\
50 & 50 & 100 \\
40 & 60 & 100 \\
30 & 70 & 100 \\
20 & 80 & 100 \\
\hline
\end{tabular}


were seeded at $5 \times 10^{4}$ cells per well into 48 -well plates. After the induction of differentiation, the cells were treated with various concentrations of the sample and incubated for an additional $24 \mathrm{~h}$ at $37^{\circ} \mathrm{C}$. MTT stock solution (100 $\mu \mathrm{L} ; 2 \mathrm{mg} / \mathrm{mL}$ in PBS) was then added to each well. After incubating for $4 \mathrm{~h}$, the plate was centrifuged at $500 \mathrm{~g}$ for $10 \mathrm{~min}$, and the supernatant was aspirated. The formazan crystals in each well were dissolved in dimethyl sulfoxide (DMSO). The amount of purple formazan was determined by measuring the absorbance at $540 \mathrm{~nm}$.

\section{Cell proliferation assay}

The cell proliferation effect of the samples on $\mathrm{C} 2 \mathrm{C} 12$ myoblasts was determined by using 5-bromo-2'-deoxyuridine (BrdU) assay (Millipore, Billerica, MA, USA). The cells were seeded at $1 \times 10^{4}$ cells per well into 48 well plates. After the induction of differentiation by switching media, the cells were treated with various concentrations of the sample and incubated for an additional $72 \mathrm{~h}$ at $37{ }^{\circ} \mathrm{C}$. Then, the cell proliferation was determined by BrdU reagent following manufacture protocol. In briefly, $10 \mu \mathrm{L}$ of BrdU reagent was added to each well and the cells were incubated for $2 \mathrm{~h}$. After incubation, the cells were fixed using $100 \mu \mathrm{L}$ fixing solution. Then, the cells were washed using wash buffer and $50 \mu \mathrm{L}$ of anti-BrdU monoclonal was added to each well and the cells were incubated for $1 \mathrm{~h}$ at RT. The cells were washed using wash buffer and $50 \mu \mathrm{L}$ of goat antimouse IgG was added to each well, and the cells were incubated for $30 \mathrm{~min}$ at RT. Also, $50 \mu \mathrm{L}$ of TMB substrate was added to each well and then, $50 \mu \mathrm{L}$ of stop solution was added to each well. Finally, the cell proliferation was calculated by comparison with the absorbance at $450 \mathrm{~nm}$ of standard solutions of BrdU in the non-treated cells.

\section{Anti-fatigue activity in oxidative stress-induced $\mathrm{C} 2 \mathrm{C} 12$ myoblasts}

The anti-fatigue activity was determined by measuring cell proliferation as well as the glycogen, ATP contents in $\mathrm{H}_{2} \mathrm{O}_{2}$-treated $\mathrm{C} 2 \mathrm{C} 12$ myoblasts. The cells were seeded into 48-well plates. Then, they were treated with various concentrations of the sample during the differentiation period. After differentiation, fatigue was induced by adding $\mathrm{H}_{2} \mathrm{O}_{2}$ to each well at a concentration of $100 \mu \mathrm{M}$; then, the cells were incubated for an additional $24 \mathrm{~h}$ at $37^{\circ} \mathrm{C}$.

\section{Measurement of fatigue-related biochemical parameters}

To investigate the effect of the samples on muscle growth, we determined several factors such as glycogen and ATP contents in $\mathrm{C} 2 \mathrm{C} 12$ myoblasts. For analysis of the effects of the sample on glycogen accumulation, the glycogen content in the cells was measured via glycogen assay (Abcam, Cambridge, MA, USA). Glucoamylase hydrolyzes glycogen to glucose, which was then specifically oxidized to form an intermediate product that reacts with OxiRed probe to generate color. The color was detected by measuring the absorbance at $450 \mathrm{~nm}$. To determine ATP contents, the cell lysates were deproteinized with $4 \mathrm{M}$ perchloric acid (PCA) and $2 \mathrm{M} \mathrm{KOH}$, and the supernatant was assessed using ATP assay kits (Abcam, Cambridge, MA, USA).

\section{Statistical analysis}

All measurements were made in triplicate, and all values were represented as means $\pm \mathrm{SE}$. The results were subjected to analysis of variance using Tukey's test to analyze the differences. $p<0.05$ and $p<0.01$ were considered significant.

\section{Results and discussion Cytotoxicity of $\mathrm{HH}$}

Cell viability was estimated using the MTT assay, which is a test of metabolic competence predicated upon the assessment of mitochondrial performance. It is a colorimetric assay, which is dependent on the conversion of yellow tetrazolium bromide to its purple formazan derivative by mitochondrial succinate dehydrogenase in the viable cells (Kang et al. 2012). The viabilities of C2C12 myoblasts treated with different concentrations of $\mathrm{HH}$ $(50,100,150$, and $200 \mu \mathrm{g} / \mathrm{mL})$ were expressed to represent $100 \%$ viability (the viability of control cells; Fig. 1 ). In a preliminary experiment, $\mathrm{HH}$ concentrations up to $200 \mu \mathrm{g} / \mathrm{mL}$ showed no significant cytotoxicity for $24 \mathrm{~h}$.

\section{Effect of $\mathrm{HH}$ on cell proliferation}

$\mathrm{HH}$ significantly enhanced cell proliferation in C2C12 myoblasts compared with the control cells (Fig. 2). In particular, $\mathrm{HH}$ treatment induced cell proliferation in a concentrationdependent manner in the range of $100-200 \mu \mathrm{g} / \mathrm{mL}$. The cell numbers increased approximately 1.8 -fold by $\mathrm{HH}$ treatment at $200 \mu \mathrm{g} / \mathrm{mL}$ concentration (Fig. 2).

\section{Effect of HH on glycogen contents}

The skeletal muscles are the major site of glycogen storage in the body (Deshmukh et al. 2015). The glycogen content in $\mathrm{C} 2 \mathrm{C} 12$ myoblasts was increased by $\mathrm{HH}$ treatment at concentrations of 50 and $100 \mu \mathrm{g} / \mathrm{mL}$ (Fig. 3). In $\mathrm{C} 2 \mathrm{C} 12$ myoblasts, $\mathrm{HH}(100 \mu \mathrm{g} / \mathrm{mL})$ increased glycogen content by 1.5 -fold compared with that in the control cells. However, $\mathrm{HH}$ treatment at higher concentrations (150 and $200 \mu \mathrm{g} / \mathrm{mL}$ ) decreased glycogen content. Thus, it can be suggested that high concentrations of $\mathrm{HH}$ suppressed glycogen content. 


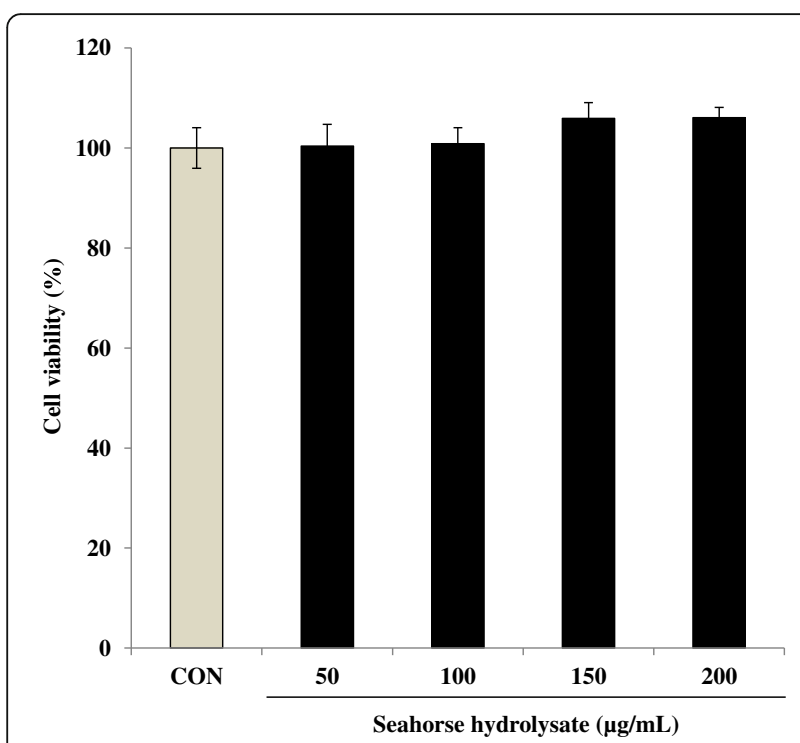

Fig. 1 Cytotoxicity of seahorse hydrolysate on C2C12 myoblasts. The cell was treated with various concentrations of seahorse hydrolysate (50, 100, 150, and $200 \mu \mathrm{g} / \mathrm{mL})$ and incubated for $24 \mathrm{~h}$. The cytotoxicity was assessed by MTT assay. The experiment was performed in triplicate. Each value indicates the mean \pm standard error from three independent experiments

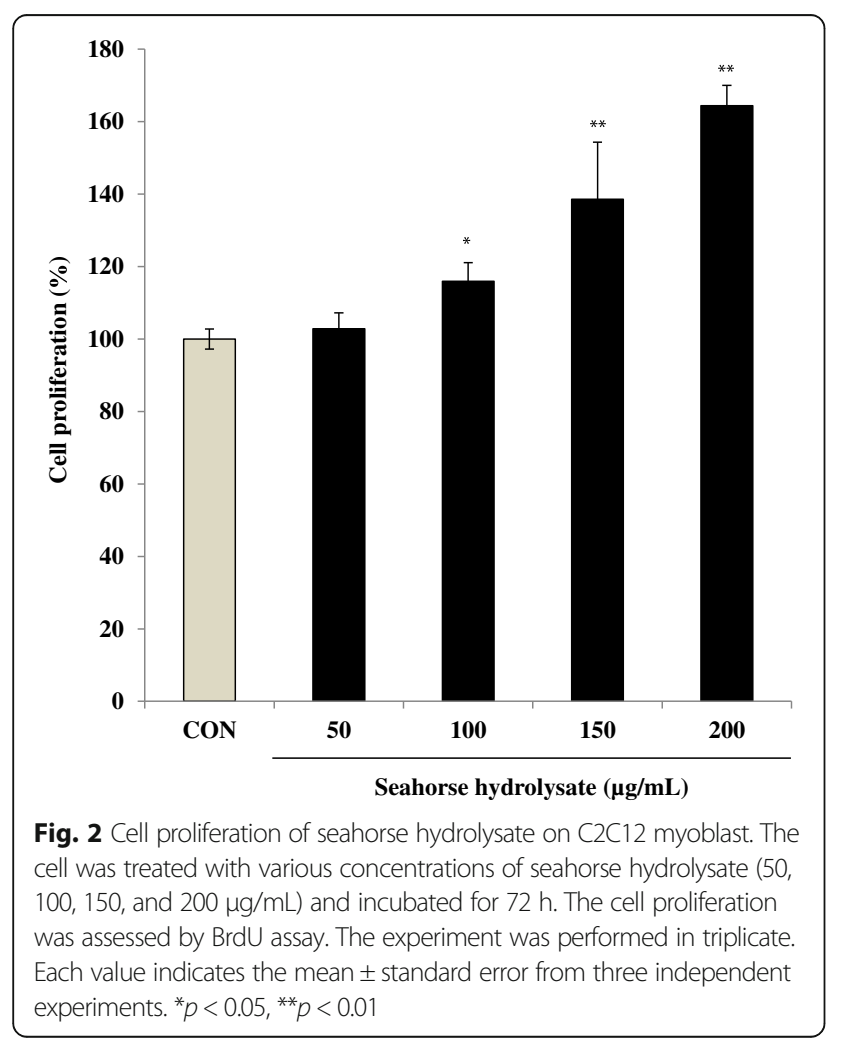

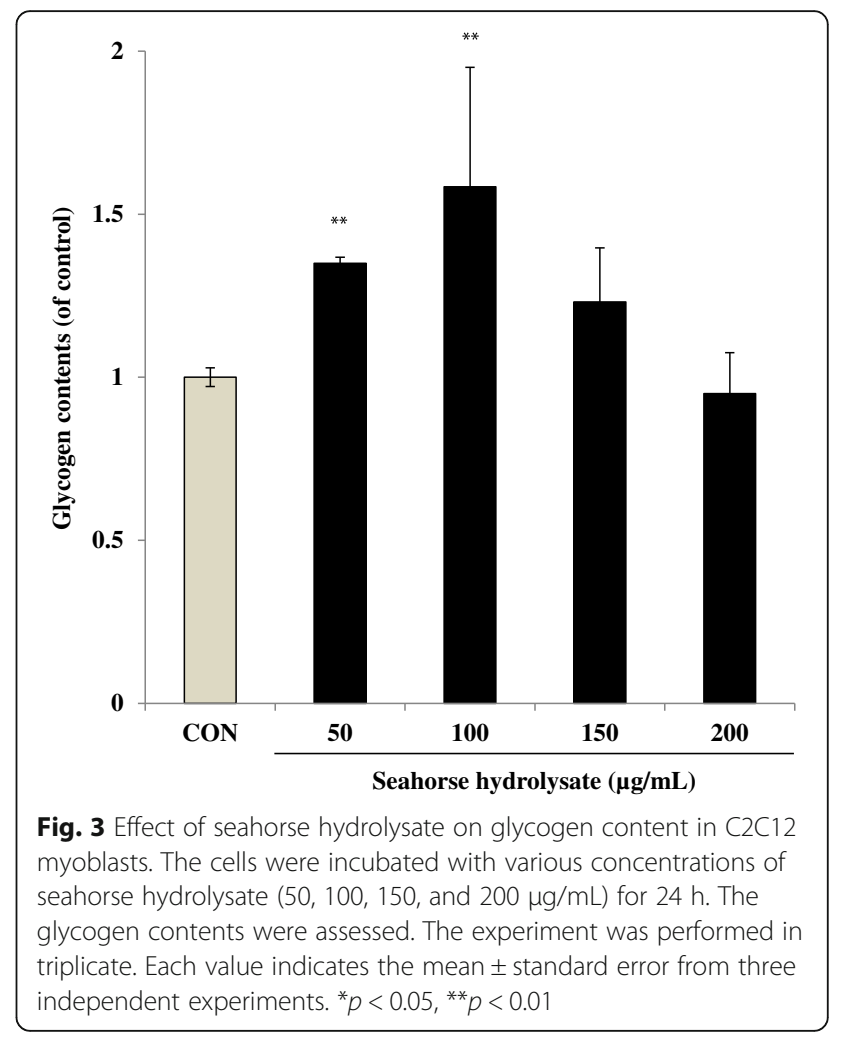

Cytotoxicity of the mixture of $\mathrm{HH}$ and RG

Although $H$. abdominalis was validated for use in food by the Ministry of Food and Drug Safety in February 2016, the validation was restricted to $20 \%$ of the entire composition. To use $H$. abdominalis as a food ingredient, we should prepare an $H$. abdominalis mixture by adding other materials.

RG has been frequently used in traditional Asian medicine to treat many disorders, such as debility, aging, stress, diabetes, and insomnia (Tang et al. 2008). Especially, RG has been mainly focused on its anti-fatigue activity with the ability mitigating exercise-related muscle damage, maintaining homeostasis of the body, and enhancing vital energy (Kim et al. 2013; Kim et al. 2016). Thus, H. abdominalis mixtures were prepared by adding different concentrations of RG $(20,30,40,50,60,70$, and $80 \%$ of RG) to investigate the synergy effect between $H$. abdominalis and RG on anti-fatigue activity.

Effect of these mixtures on cell viability was estimated using the MTT assay. The viabilities of $\mathrm{C} 2 \mathrm{C} 12$ myoblasts treated with the mixtures at different concentrations (50, $100,200,250$, and $500 \mu \mathrm{g} / \mathrm{mL}$ ) were expressed to represent over $90 \%$ viability, which was similar to that of the control cells (Fig. 4). Thus, mixtures up to $500 \mu \mathrm{g} / \mathrm{mL}$ concentration did not show any significant cytotoxicity for $24 \mathrm{~h}$.

Effect of the mixture of $\mathrm{HH}$ and RG on cell proliferation To assess the effect of $\mathrm{HH}(0 \%$ of $\mathrm{RG})$ and RG mixture on muscle growth, cell proliferation was measured as 


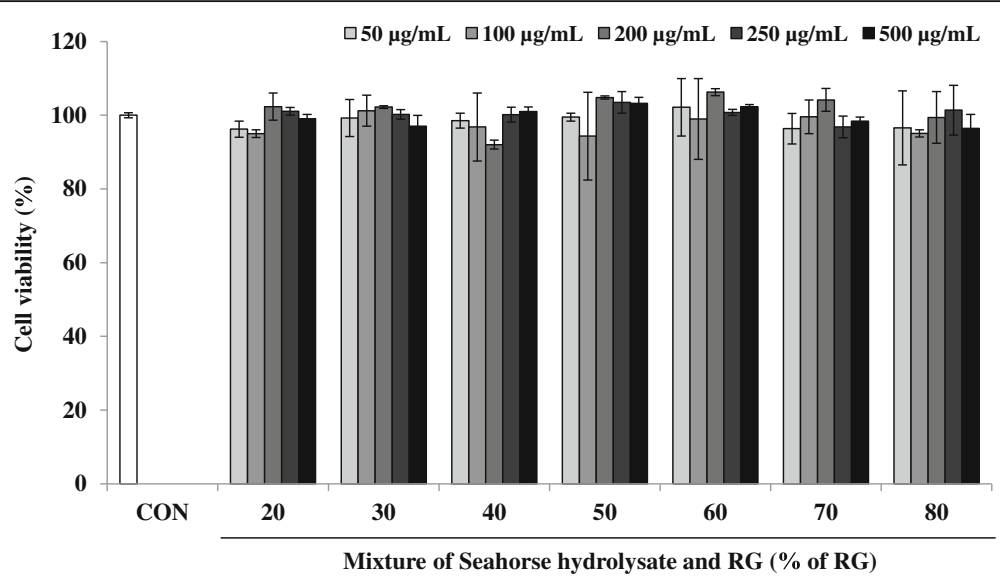

Fig. 4 Cytotoxicity of the six mixtures of seahorse hydrolysate and RG on C2C12 myoblasts. The cell was treated with various concentrations of the six mixtures $(50,100,150,200,250$, and $500 \mu \mathrm{g} / \mathrm{mL}$ ) and incubated for $24 \mathrm{~h}$. The cytotoxicity was assessed by MTT assay. The experiment was performed in triplicate. Each value indicates the mean \pm standard error from three independent experiments

shown in Fig. 5. HH and RG mixtures showed the significant effect on cell proliferation. Especially, at the low concentrations (200 and $250 \mu \mathrm{g} / \mathrm{mL}$ ), $\mathrm{HH}$ significantly enhanced proliferation of $\mathrm{C} 2 \mathrm{C} 12$ myoblasts compared with that of mixtures as well as that of the control cells. However, at the high concentrations (400 and $500 \mu \mathrm{g} /$ $\mathrm{mL}), \mathrm{HH}$ and RG mixtures did not show any significant effects on cell proliferation to each other.

\section{Anti-fatigue activity of the mixtures of HH and RG}

Several biomarkers such as lactate dehydrogenase (LDH), glycogen, aspartate transaminase (AST), and alanine transaminase (ALT) have been used to investigate muscle injury during exhaustive exercise (Huang et al. 2015). Also, fatigue is related to mitochondrial dysfunction and diminished ATP levels (Singh and Singh 2014).
The anti-fatigue activity of the mixtures of $\mathrm{HH}$ and $\mathrm{RG}$ was assessed in $\mathrm{H}_{2} \mathrm{O}_{2}$-treated $\mathrm{C} 2 \mathrm{C} 12$ myoblasts by measuring cell proliferation as well as the glycogen and ATP contents. Severe and continuous exercise may elevate the formation of ROS, thereby increasing oxidative stress. A sustained elevated oxidative stress can hamper mitochondrial function resulting in low ATP synthesis and increased lactic acid in the muscles, consequently decreasing the physical efficiency. These observations suggest that improving the antioxidant status may enhance the overall physical performance by maintaining the pro-oxidant/antioxidant balance (Swamy et al. 2011). To induce oxidative stress in $\mathrm{C} 2 \mathrm{C} 12$ myoblasts, the cells were incubated with $\mathrm{H}_{2} \mathrm{O}_{2}$ at a concentration of $100 \mu \mathrm{M}$. After $\mathrm{H}_{2} \mathrm{O}_{2}$ treatment, the viability of $\mathrm{C} 2 \mathrm{C} 12$ myoblasts decreased to less than $60 \%$ compared to that

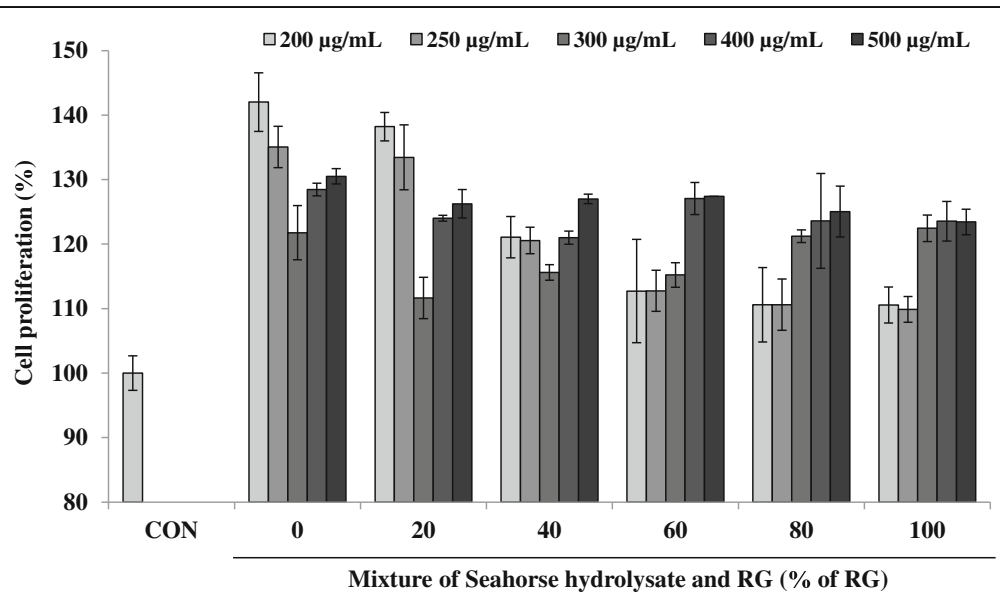

Fig. 5 Cell proliferation of the six mixtures of seahorse hydrolysate and RG on C2C12 myoblast. The cell was treated with various concentrations of the six mixtures (50, 100, 150, and $200 \mu \mathrm{g} / \mathrm{mL}$ ) and incubated for $72 \mathrm{~h}$. The cell proliferation was assessed by BrdU assay. Effect of different mixtures of seahorse hydrolysate and RG on C2C12 myoblast proliferation. The experiment was performed in triplicate. Each value indicates the mean \pm standard error from three independent experiments 


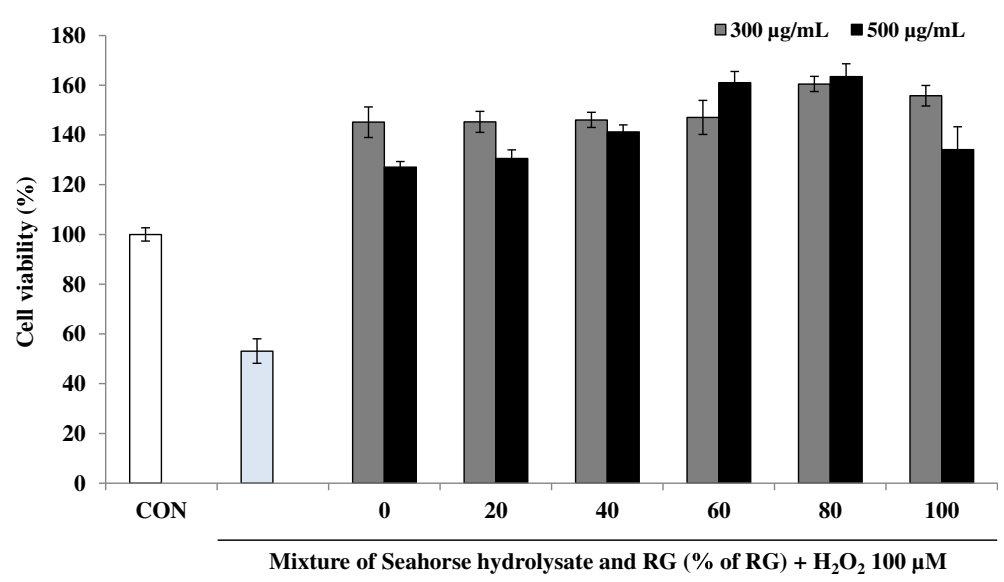

Fig. 6 Protective effect of the six mixtures of seahorse hydrolysate and $\mathrm{RG}$ against $\mathrm{H}_{2} \mathrm{O}_{2}$-treated $\mathrm{C}_{2} \mathrm{C} 12$ myoblasts. The treatment of $\mathrm{H}_{2} \mathrm{O}_{2}$ induced a decrease in cell viability. All mixtures showed protective effect on $\mathrm{H}_{2} \mathrm{O}_{2}$-induced oxidative stress in $\mathrm{C} 2 \mathrm{C} 12$ myoblasts. The experiment was performed in triplicate. Each value indicates the mean \pm standard error from three independent experiments

in the control cells (Fig. 6). However, C2C12 myoblasts treated with $\mathrm{HH}$ and RG mixtures showed increased viability compared with that reported for the control cells. Notably, at a sample concentration of $500 \mu \mathrm{g} / \mathrm{mL}$, cell viability increased steadily with increasing percentage of RG except at $100 \%$ RG, where only RG was present in the mixture.

\section{Glycogen contents}

Energy expenditure during exercise leads to physical fatigue, which is mainly caused by energy consumption and deficiency. Catabolized fat and carbohydrates are considered the main sources of energy in the skeletal muscles during exercise, and glycogen is the predominant source of glycolysis for energy production. Therefore, glycogen storage directly affects exercise ability (Wu et al. 2013). The glycogen content of the $\mathrm{H}_{2} \mathrm{O}_{2}$ - treated cells was lower than that of the control cells. However, in $\mathrm{C} 2 \mathrm{C} 12$ myoblasts, the treatment with $\mathrm{HH}$ and RG mixtures increased the glycogen content to more than double as compared to the values reported for the control cells. In particular, RG60, RG80, and RG100 showed increased glycogen content at a sample concentration of 300 and $500 \mu \mathrm{g} / \mathrm{mL}$ (Fig. 7).

\section{ATP contents}

Muscular exercise causes rapid ATP consumption, and energy deficiency is a critical reason for physical fatigue. Therefore, compounds that promote ATP production could be candidates for alleviating physical fatigue. The skeletal muscle mainly catabolizes fat and carbohydrates as sources of energy during exercise (Nozawa et al. 2009). ATP content in the $\mathrm{H}_{2} \mathrm{O}_{2}$-treated cells was lower than that in the control cells (Fig. 8). Although HH and

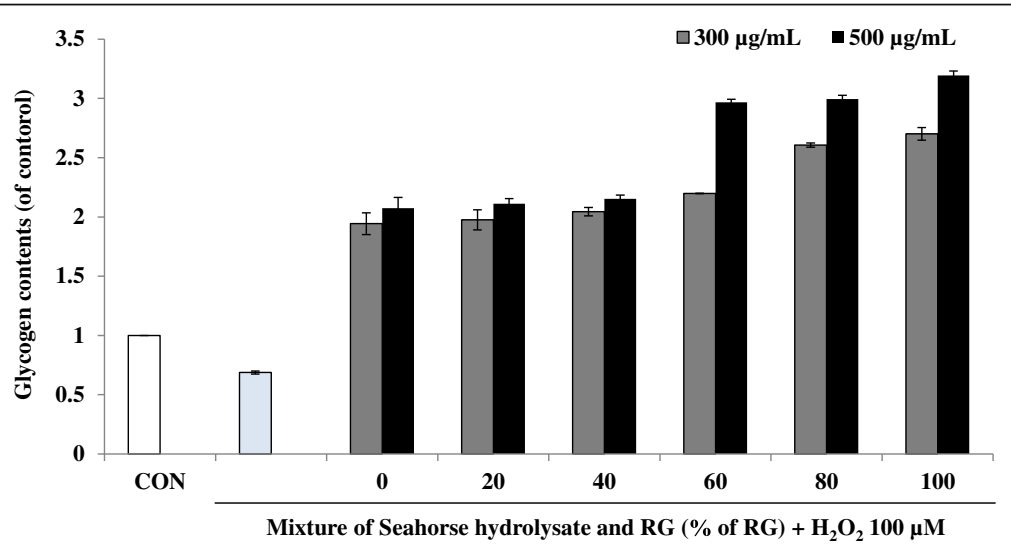

Fig. 7 Effect of the six mixtures of seahorse hydrolysate and $\mathrm{RG}$ on glycogen content in $\mathrm{H}_{2} \mathrm{O}_{2}$-treated $\mathrm{C} 2 \mathrm{C} 12$ myoblasts. $\mathrm{H}_{2} \mathrm{O}_{2}$ treatment induced a decrease in glycogen contents. All mixtures showed protective effect on $\mathrm{H}_{2} \mathrm{O}_{2}$-induced oxidative stress in $\mathrm{C} 2 \mathrm{C} 12$ myoblasts. The experiment was performed in triplicate. Each value indicates the mean \pm standard error from three independent experiments 


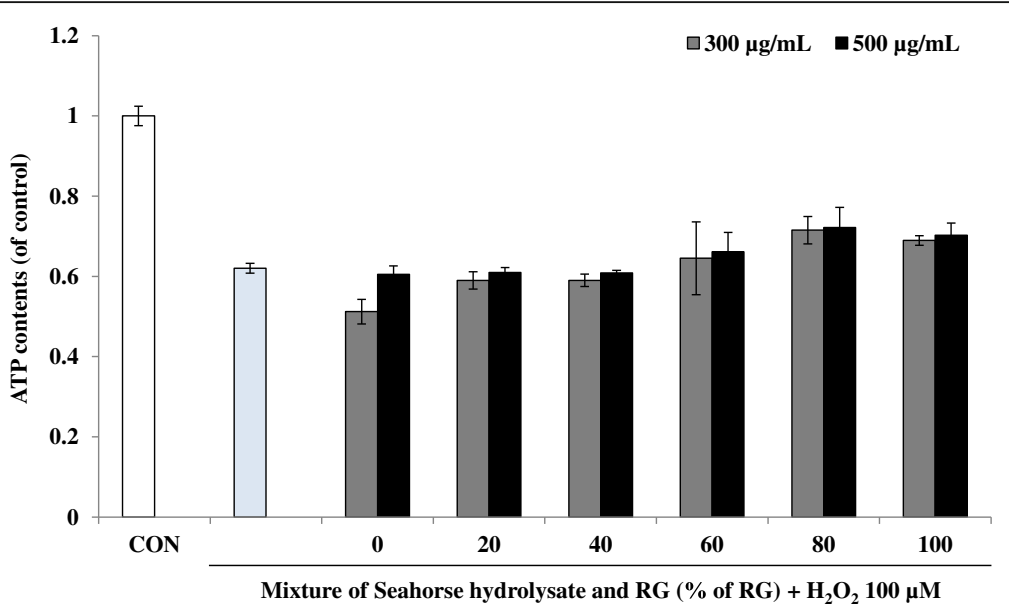

Fig. 8 Effect of the six mixtures of seahorse hydrolysate and RG on ATP synthesis in $\mathrm{H}_{2} \mathrm{O}_{2}$-treated $\mathrm{C}_{2} \mathrm{C} 12$ myoblasts. The treatment of $\mathrm{H}_{2} \mathrm{O}_{2}$ induced a decrease in ATP contents. All mixtures showed a protective effect against $\mathrm{H}_{2} \mathrm{O}_{2}$-induced oxidative stress in $\mathrm{C} 2 \mathrm{C} 12$ myoblasts. The experiment was performed in triplicate. Each value indicates the mean \pm standard error from three independent experiments

RG mixtures did not increase the ATP content, RG80 relatively increased the ATP content at 300 and $500 \mu \mathrm{g} /$ $\mathrm{mL}$ concentrations of the mixture.

Exercise-induced oxidative stress can cause the increased muscle fatigability. Thus, antioxidants can decrease the oxidative stress and improve the physiological condition (You et al. 2011). Some reports showed that a loach peptide has not only antioxidant activities but also an anti-fatigue effect in mice (You et al. 2011). Actually, the peptide showing in vitro antioxidant activity possesses the in vivo anti-fatigue activity. The peptide acts as the scavenger for DPPH and hydroxyl radicals. Also, the anthocyanins of mulberry fruit have been assessed in vitro antioxidant activity and in vivo anti-fatigue activity (Jiang et al. 2013). These studies showed values of in vitro study to evaluate the potential anti-fatigue activity through in vivo study. In the present study, the mixtures of $\mathrm{HH}$ and RG acted as the antioxidant for hydrogen peroxide and showed the anti-fatigue activity on $\mathrm{C} 2 \mathrm{C} 12$ myoblast. Furthermore, the mixtures have valuable needs to be investigated through in vivo animal study.

\section{Conclusions}

In this study, the effect of $H$. abdominalis on the muscles was investigated to scientifically verify its potential bioactivity. Also, the anti-fatigue activity of a mixture comprising $\mathrm{HH}$ and RG was evaluated to commercially utilize $H$. abdominalis in food industry. The treatment of $\mathrm{HH}$ to $\mathrm{C} 2 \mathrm{C} 12$ myoblast induced the cell proliferation and glycogen contents. These results indicated that $H$. abdominalis had anti-fatigue activity on $\mathrm{C} 2 \mathrm{C} 12$ myoblast. Moreover, the treatment of the mixture comprising $\mathrm{HH}$ and RG increased cell viability and the content of fatigue-related biomarkers such as glycogen and ATP contents. In particular, the $80 \%$ RG mixture showed an optimum effect on cell viability and ATP synthesis activity. These results indicated that $\mathrm{HH}$ had anti-fatigue activity at concentrations approved for use in food by the law in Korea. Especially, an 80\% RG to HH mixture has the potential to ameliorate fatigue condition induced by oxidative stress by increasing the fatigue-related biochemical parameters such as glycogen and ATP contents in $\mathrm{C} 2 \mathrm{C} 12$ myoblasts. Therefore, $80 \% \mathrm{RG}$ to $\mathrm{HH}$ mixture can be used in food for ameliorating fatigue in Korea.

\section{Abbreviations \\ $\mathrm{HH}$ : Hippocampus abdominalis; RG: Red ginseng}

\section{Acknowledgements}

This research was financially supported by the Ministry of Trade, Industry, and Energy (MOTIE), Korea, under the "Regional Specialized Industry Development

Program" supervised by the Korea Institute for Advancement of Technology (KIAT).

\section{Funding}

This study was funded from the Ministry of Trade, Industry, and Energy (MOTIE), Korea.

\section{Availability of data and materials}

The datasets supporting the conclusions of the article are included within the article. There is no additional data and materials to disclose.

\section{Authors' contributions}

NK contributed to conduct the research and prepare the draft manuscript. SYK contributed to conduct the cell experiments and analyze the biomarker levels. SR managed aquaculture of the seahorse and supported it for this study. JYK contributed to design the study and conduct the experiments. YJJ contributed to monitor the experiments and finalize the manuscript. All authors read and approved the final manuscript.

\section{Competing interests}

The authors declare that they have no competing interests.

\section{Consent for publication}

The manuscript has been read and approved by the authors, and none of its parts have been submitted and published elsewhere. The authors also declare that nobody who qualifies for authorship has been excluded from the list of authors. 


\section{Ethics approval and consent to participate}

Not applicable.

\section{Author details}

${ }^{1}$ Department of Marine Life Sciences, Jeju National University, Jeju 63243, Korea. ${ }^{2}$ Center of Ornamental Reefs and Aquariums, Jeju 63354, Korea.

Received: 22 December 2016 Accepted: 14 February 2017

\section{Published online: 17 March 2017}

\section{References}

Deshmukh AS, Murgia M, Nagaraj N, Treebak JT, Cox J, Mann M. Deep proteomics of mouse skeletal muscle enables quantitation of protein isoforms, metabolic pathways, and transcription factors. Mol Cell Proteomics. 2015;14:841-53.

Fan H, Tan Z, Hua Y, Huang X, Gao Y, Wu Y, Liu B, Zhou Y. Deep sea water improves exercise and inhibits oxidative stress in a physical fatigue mouse model. Biomed Rep. 2016;4:751-7.

Huang L-Z, Huang B-K, Ye Q, Qin L-P. Bioactivity-guided fractionation for antifatigue property of Acanthopanax senticosus. J Ethnopharmacol. 2011;133: 213-9.

Huang W-C, Lin C-I, Chiu C-C, Lin Y-T, Huang W-K, Huang H-Y, Huang C-C. Chicken essence improves exercise performance and ameliorates physical fatigue. Nutrients. 2014;6:2681-96.

Huang W-C, Chiu W-C, Chuang H-L, Tang D-W, Lee Z-M, Wei L, Chen F-A, Huang C-C. Effect of curcumin supplementation on physiological fatigue and physical performance in mice. Nutrients. 2015;7:905-21.

Jiang D-Q, Guo Y, Xu D-H, Huang Y-S, Yuan K, Lv Z-Q. Antioxidant and anti-fatigue effects on anthocyanins of mulberry juice purification (MJP) and Mulberry marc purification (MMP) from different varieties mulberry fruit in China. Food Chem Toxicol. 2013;59:1-7.

Kang S-M, Heo S-J, Kim K-N, Lee S-H, Jeon Y-J. Isolation and identification of new compound, 2, 7"-phloroglucinol-6, 6'-bieckol from brown algae, Ecklonia cava and its antioxidant effect. J Funct Foods. 2012;4:158-66.

Kang N, Ko S-C, Samarakoon K, Kim E-A, Kang M-C, Lee S-C, Kim J, Kim Y-T, Kim J-S, Kim H. Purification of antioxidative peptide from peptic hydrolysates of Mideodeok (Styela clava) flesh tissue. Food Sci Biotechnol. 2013;22:541-7.

Kim H-G, Cho J-H, Yoo S-R, Lee J-S, Han J-M, Lee N-H, Ahn Y-C, Son C-G. Antifatigue effects of Panax ginseng CA Meyer: a randomised, double-blind, placebo-controlled trial. PLoS One. 2013;8:e61271.

Kim S, Kim J, Lee Y, Seo MK, Sung DJ. Anti-fatigue effects of acute red ginseng intake in recovery from repetitive anaerobic exercise. Iran J Public Health. 2016:45:387-9.

Kumaravel K, Ravichandran S, Balasubramanian T, Siva Subramanian K, Bilal A. Antimicrobial effect of five seahorse species from Indian coast. Br J Pharmacol Toxicol. 2010;1:62-6.

Kumaravel K, Ravichandran S, Balasubramanian T, Sonneschein L. Seahorses-a source of traditional medicine. Nat Prod Res. 2012;26:2330-4.

Nam S-Y, Kim H-M, Jeong H-J. Anti-fatigue effect by active dipeptides of fermented porcine placenta through inhibiting the inflammatory and oxidative reactions. Biomed Pharmacother. 2016;84:51-9.

Nozawa Y, Yamada K, Okabe Y, Ishizaki T, Kuroda M. The anti-fatigue effects of the low-molecular-weight fraction of bonito extract in mice. Biol Pharm Bull. 2009;32:468-74

Perera N, Godahewa G, Lee J. Copper-zinc-superoxide dismutase (CuZnSOD), an antioxidant gene from seahorse (Hippocampus abdominalis); molecular cloning, sequence characterization, antioxidant activity and potential peroxidation function of its recombinant protein. Fish Shellfish Immunol. 2016;57:386-99.

Qian Z-J, Kang K-H, Kim S-K. Isolation and antioxidant activity evaluation of two new phthalate derivatives from seahorse, Hippocampus kuda Bleeler. Biotechnol Bioprocess Eng. 2012;17:1031-40.

Segade Á, Robaina L, Otero-Ferrer F, García Romero J, Molina Domínguez L. Effects of the diet on seahorse (Hippocampus hippocampus) growth, body colour and biochemical composition. Aquacult Nutr. 2015;21:807-13.

Singh T, Singh K. Mitochondrial dysfunction and chronic fatigue syndromes: issues in clinical care (modified version). IOSR J Dental Med Sci. 2014;13:30-3.

Swamy M, Naveen S, Singsit D, Naika M, Khanum F. Anti-fatigue effects of polyphenols extracted from pomegranate peel. Int J Integr Biol. 2011;11:69-72

Tang W, Zhang Y, Gao J, Ding X, Gao S. The anti-fatigue effect of 20 (R)ginsenoside Rg3 in mice by intranasally administration. Biol Pharm Bull. 2008; 31:2024-7.
Wu R-E, Huang W-C, Liao C-C, Chang Y-K, Kan N-W, Huang C-C. Resveratrol protects against physical fatigue and improves exercise performance in mice. Molecules. 2013;18:4689-702.

You L, Zhao M, Regenstein J-M, Ren J. In vitro antioxidant activity and in vivo anti-fatigue effect of loach (Misgurnus anguillicaudatus) peptides prepared by papain digestion. Food Chem. 2011;124:188-94.

Yu B, Lu Z-X, Bie X-M, Lu F-X, Huang X-Q. Scavenging and anti-fatigue activity of fermented defatted soybean peptides. Eur Food Res Technol. 2008;226:415-21.

Zhang Y, Yao X, Bao B, Zhang Y. Anti-fatigue activity of a triterpenoid-rich extract from Chinese bamboo shavings (Caulis bamfusae in taeniam). Phytother Res. 2006;20:872-6.

\section{Submit your next manuscript to BioMed Central and we will help you at every step:}

- We accept pre-submission inquiries

- Our selector tool helps you to find the most relevant journal

- We provide round the clock customer support

- Convenient online submission

- Thorough peer review

- Inclusion in PubMed and all major indexing services

- Maximum visibility for your research

Submit your manuscript at www.biomedcentral.com/submit
C) Biomed Central 